\title{
Citizen science and natural resource governance: program design for vernal pool policy innovation
}

\author{
Bridie McGreavy $^{1}$, Aram J. K. Calhoun $^{2}$, Jessica Jansujwicz $^{3}$ and Vanessa Levesque $^{4}$
}

\begin{abstract}
Effective natural resource policy depends on knowing what is needed to sustain a resource and building the capacity to identify, develop, and implement flexible policies. This retrospective case study applies resilience concepts to a 16-year citizen science program and vernal pool regulatory development process in Maine, USA. We describe how citizen science improved adaptive capacities for innovative and effective policies to regulate vernal pools. We identified two core program elements that allowed people to act within narrow windows of opportunity for policy transformation, including (1) the simultaneous generation of useful, credible scientific knowledge and construction of networks among diverse institutions, and (2) the formation of diverse leadership that promoted individual and collective abilities to identify problems and propose policy solutions. If citizen science program leaders want to promote social-ecological systems resilience and natural resource policies as outcomes, we recommend they create a system for internal project evaluation, publish scientific studies using citizen science data, pursue resources for program sustainability, and plan for leadership diversity and informal networks to foster adaptive governance.
\end{abstract}

Key Words: adaptive governance; citizen science; leadership; natural resource policy; vernal pools

\section{INTRODUCTION}

Success in linking science with decision-making is a hallmark of effective natural resource management and policy (Palmer 2012). To achieve this goal, policies need to approach natural resource issues as occurring within complex social-ecological systems (SES) and be based on science that is informed by multiple perspectives to produce evidence that is credible and useful to key stakeholders (Folke et al. 2002, Berkes and Folke 2000, Cash et al. 2003, Chapin et al. 2009, Boyd and Folke 2012). Involving diverse stakeholders in science can generate useful knowledge and build support for regulating difficult-to-conserve natural resources, including wetlands (Hart and Calhoun 2010). Conserving wetlands has been a challenge in the United States (U.S.), with wetland filling and degradation outpacing conservation efforts until very recently (Tiner 2009). Small ephemeral wetlands, such as vernal pools, are particularly vulnerable because they occur on private property (Mahaney and Klemens 2008). Even modest state and federal regulations have caused strong public resistance and court cases focused on private property rights (i.e., U.S. versus Solid Waste Association of Northern Cook County in 2001; U.S. versus Rapanos in 2006). Federal and state listing of some vernal pool-dependent species in New England has heightened attention for the need to conserve this resource.

In Maine, a state in the northeastern United States, a nongovernmental environmental organization, a land-grant university, and state regulators identified the need to understand vernal pool ecology to inform eventual regulation in the mid-1990s (Jansujwicz and Calhoun 2010). These stakeholders initiated a citizen science program to provide more information about pool ecology to natural resource managers and to raise public awareness of vernal pools. At the time, citizen science was a relatively new approach to engage "non-professionals in scientific investigations - asking questions, collecting data, or interpreting results" in partnerships that often also involve scientists (Miller-Rushing et al. 2012:285). Those working on developing knowledge about vernal pools turned to citizen science because, as has since been shown, this approach can increase the size and scale of long-term data sets about ecological and social systems (Dickinson and Bonney 2012). Many citizen science programs concentrate on understanding complex humanenvironment interactions (Dickinson et al. 2010, Crain et al. 2014), and improving ecosystem stewardship (Couvet et al. 2008, Crall et al. 2012, McKinley et al. 2012). With important exceptions (Jordan et al. 2011), a growing body of scholarship demonstrates how citizen science programs can positively impact learning, attitudes about the environment, and ecological literacy (Brossard et al. 2005, Bonney et al. 2009, Crall et al. 2012, Jordan et al. 2012).

The process of designing citizen science programs to promote specific policy and capacity-related outcomes like ecological literacy and SES resilience is still nascent (Phillips et al. 2012, Shirk et al. 2012, Jordan et al. 2015). In our use, resilience refers to the ability "to respond to and shape change in ways that both sustain and develop the same fundamental function, structure, identity, and feedback" (Chapin et al. 2009:5), a definition that aligns with the evolving goals of the vernal pool regulatory efforts, which seek to maintain functioning vernal pool systems and healthy human communities. Our case study documents how citizen science fits into the SES resilience puzzle, as we show how citizen science program design elements contributed to the formation of adaptive governance in ways that influence how vernal pools as SES respond to change. Though the role of knowledge, networks, and leadership in the development of adaptive governance has been well documented (cf. Olsson et al. 2004a, b, Bodin and Prell 2011, Boyd and Folke 2012), our analysis

\footnotetext{
${ }^{1}$ Department of Communication and Journalism, Senator George J. Mitchell Center for Sustainability Solutions, University of Maine, ${ }^{2}$ Department of Wildlife, Fisheries, and Conservation Biology, University of Maine, ${ }^{3}$ Senator George J. Mitchell Center for Sustainability Solutions, University of Maine, ${ }^{4}$ Department of Sustainability, University of New Hampshire
} 
examines the specific relationship between citizen science and the emergence of adaptive forms of governance for SES resilience.

\section{Vernal pools, citizen science, and SES resilience}

Resilience is a useful framework because it directs our attention to complex interactions and dependencies between humans and ecosystems and the capacity of systems to absorb change (Lebel et al. 2006, Chapin et al. 2009, Folke et al. 2010). In this section, we identify and describe the relationships between (1) our resilience goal of maintaining healthy vernal pool ecosystems and human communities; (2) how citizen science advances this goal by building adaptive capacities through knowledge, networks, and leadership; and (3) how these adaptive capacities can support the transformation of policies that constrain adaptive forms of governance (Fig. 1).

Fig. 1. The identified resilience goal requires the development of adaptive capacity. Citizen science is an approach to socialecological systems (SES) resilience that can promote the development of new knowledge and the formation of networks that together produce outputs and outcomes that transform key stressors.

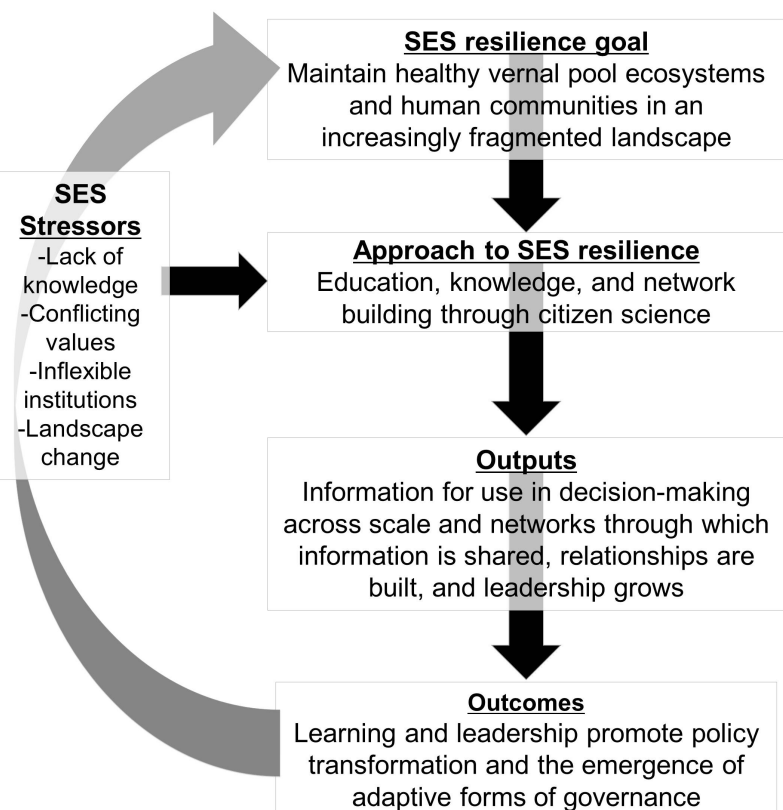

SES resilience goal: Maintaining healthy vernal pools and human communities

Starting in the mid-1990s, Maine-based conservation and regulatory efforts sought to bring science to bear on defining vernal pool SES resilience, implicitly addressing from the earliest stages the essential question of the resilience of what, to what, and for whom (Lebel et al. 2006). Vernal pools in New England are relatively small (often $<0.2$ ha) seasonal wetlands embedded in forested landscapes. They typically dry every year, refill in spring, and provide breeding habitat for a suite of invertebrate and amphibian species that are adapted to life in temporary waters
(Colburn 2004). In New England, signature species include wood frogs (Lithobates sylvaticus) and a number of ambystomatid salamanders (Ambystoma spp.). The adults breed in the pools for a short period each spring or fall and spend the rest of their lives in surrounding forests, often at distances of hundreds of meters from breeding pools (Calhoun and deMaynadier 2008). Vernal pools offer several challenges to effective documentation as they are ephemeral, not widely known or appreciated, and difficult to map remotely (Dibello et al. 2016).

Given these social and ecological characteristics, scientists and regulators identified the desired goal of maintaining or creating landscapes with interconnected vernal pool complexes; human communities that understand and appreciate the multiple ecosystem services and values associated with vernal pools; and conservation policies and strategies that preserve private property rights and economic development opportunities (Calhoun et al. 2014). Collaborators also identified how maintaining or achieving these goals is threatened by stressors such as rapid and largely unplanned landscape development; policies that do not adequately regulate vernal pools as interconnected ecosystems; and relatively unknown changes related to climate, invasive species, and demographic shifts (Kneitel 2014, Tuytens et al. 2014).

\section{Approach to SES resilience: Building adaptive capacities through} citizen science

Adaptive capacities are crucial for maintaining ecosystem services, reducing the sensitivity of a system to change, promoting the persistence of desired system states, and implementing strategies to transform the system when necessary (Chapin et al. 2009). Connectivity and diversity have been identified as key SES features that can shape the capacity of systems to respond to change (Dietz et al. 2003, Folke et al. 2005). In social terms, the diversity of participants and their degree of connectedness influence the flow of information, learning, and the development of insights for problem solving (Olsson et al. 2004a, Crona and Bodin 2012). When people come together to produce knowledge, such as in citizen science, the process does not occur in a vacuum but instead "tends to evolve with working rules and organizational dynamics" (Olsson et al. 2004a:76) that create the social order in which knowledge is used (Jasanoff 2004).

Processes where participants from nested, diverse, and partially redundant sets of institutions engage in robust deliberation about problems and policies can promote the formation of adaptive governance (Dietz et al. 2003). Adaptive governance refers to the capacity of actors and institutions to confront complexity, uncertainty, and change by developing rules that are flexible and can evolve to fit a specific situation (Dietz et al. 2003, Boyd and Folke 2012). This approach to governance "seem[s] to be preceded by the emergence of informal networks that help to facilitate information flows, identify knowledge gaps, and create nodes of expertise of significance for ecosystem management that can be drawn upon at critical times" (Olsson et al. 2006:12). Flexible networks have played a key role in promoting governance in a wide range of ecosystem management contexts (Anderies et al. 2006, Goldstein 2008, Sendzimir et al. 2008). Citizen science programs can be designed to fill knowledge gaps, connect diverse institutions, and build relationships among researchers, policy- 
makers, resource managers, and citizens (Lowman et al. 2009, McKinley et al. 2012), and thereby contribute to the formation of adaptive governance.

\section{Knowledge and leadership for learning, policy, and adaptive governance}

Transformative learning, in which participants produce and deliberate knowledge in ways that fundamentally change their understanding, is also a precursor to adaptive governance (Folke et al. 2005, 2009, Olsson et al. 2006, Pahl-Wostl 2009). Leadership is a key factor in promoting transformative learning and the formation of adaptive governance (Olsson et al. 2004b, Gelcich et al. 2010). Leadership emphasizes the ability of participants to identify and pursue objectives and "how strategies for change play out in multilevel, multiphase contexts" (Olsson et al. 2014). Importantly, leadership does not occur through a single individual but instead is created and facilitated through the complex interactions of many (Marion and Uhl-Bien 2001, Crona et al. 2011, Levesque et al. 2016). In this sense, leadership is an emergent phenomenon that does not reside in a single person, though entrepreneurial individuals can help foster the conditions for leadership within an organization (Olsson et al. 2004b, Crona et al. 2011). Participants working in a leadership-rich context are uniquely positioned to facilitate and enhance the "cross-scale linkages for communication and learning at various levels of governance" (Crona and Bodin 2012:28; see also Seixas and Berkes 2003, Olsson et al. 2004b). Citizen science programs can be designed to promote these linkages and the conditions for learning and leadership.

The demonstrated importance of adaptive capacities and governance for effective natural resource management led us to ask (1) how did the citizen science program influence the development of an innovative and flexible landscape scale policy for vernal pools, and (2) what citizen science program elements supported the formation of adaptive governance? We draw from the above discussions of resilience to support our analysis of a long-term citizen science and vernal pool policy effort. After describing our case study methodology, we summarize activities and phases of the citizen science programs and then analyze the three primary ways in which citizen science improved adaptive capacities, fostered adaptive governance, and promoted SES resilience. First, the citizen science program filled knowledge gaps about the system, helped identify policy options that promoted vernal pool persistence in ways that also balanced human needs, and created the foundation for the formation of new networks. Second, the program design fostered the development of multiple forms of leadership that enhanced information sharing and learning. Third, the confluence of knowledge, networks, and leadership helped collaborators identify and be ready to act within windows of opportunity to address problems and implement innovative solutions, including policy transformation (Olsson et al. 2006) (Fig. 2). We conclude with recommendations for how natural resource managers and researchers can employ citizen science to support the development of science-based policies and navigate the complex challenge of regulating natural resources on private property.

\section{CASE STUDY METHODOLOGY}

We use a case study methodology to analyze an archive of materials drawn from 16 years of a citizen science program and vernal pool regulatory policy process (Yin 2013). Case study is the most appropriate methodology for this context because we have multiple and overlapping forms of evidence, and our data collection and analysis is informed by prior theoretical propositions drawn from SES literature (Yin 2013). We analyzed an archive of manuscripts and data generated by social scientists associated with the project who were studying municipal official perceptions about vernal pools (McGreavy et al. 2012), landowner and municipal official perceptions about the citizen science programs (Jansujwicz et al. 2013a, b), and the role of collaborative networks in creating innovative vernal pool policy (Levesque et al. 2016). We drew interview quotes primarily from this latter and most recent component of the broader research program, where researchers conducted key informant interviews $(n=27)$ with participants who attended three or more of the Vernal Pool Streamlining Working Group meetings. In addition to these data sets, we systematically reviewed an extensive set of published articles that describe different parts of this effort (e.g., Calhoun et al. 2003, 2014, Oscarson and Calhoun 2007, Calhoun and Reilly 2008). We also reviewed project documents and reports, websites (Calhoun et al. 2010), and a documentary produced by the Maine Public Broadcasting Network called Pools, Policies, and People (http://video.mpbn.net/video/2282308778/). Finally, we engaged in a retrospective analysis based on our respective participation in the development of the citizen science and regulatory programs to guide our explanation building (Yin 2013).

Fig. 2. The citizen science program design shaped the data collection, education programs, and collaboration in ways that fostered necessary outputs such as information for use in policy decision-making and networks for broader information sharing and relationship building. These outputs supported transformative learning processes and leadership that were essential to the formation of innovative policies and adaptive governance. (SES: social-ecological systems)

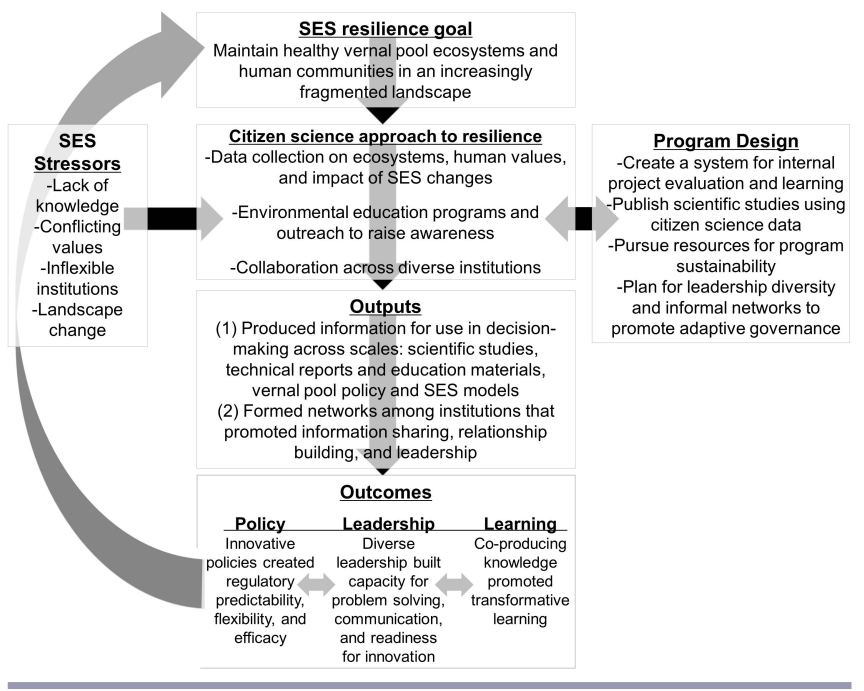

\section{A CASE STUDY OF CITIZEN SCIENCE AND SES RESILIENCE}

Our analysis of this case focuses on six distinct phases within this ongoing effort (Box 1) (see Calhoun et al. 2014 for detailed program descriptions). 


\section{Box 1:}

I. Vernal Pool Working Group (mid-1990s)

II. Very Important Pool Program (1999-2004)

III. 2007 Significant Vernal Pool Regulation

IV. Vernal Pool Mapping and Assessment Program (2007-2012)

V. Vernal Pool Streamlining Working Group (2010-present)

VI. Maine Vernal Pool Special Area Management Plan (SAMP)

\section{Citizen science approach to resilience}

Data collection, environmental education, and collaboration A municipal official involved with the vernal pool policy development characterized the process as having "come out of an initial stage of inventorying and involving citizen scientists and so forth, which in turn emerged out of a stage of new vernal pool regulation, getting them incorporated as significant habitat...So it's been incremental. It's been building." Initial attempts to develop regulations for vernal pools identified the need for science to improve basic knowledge about pool ecology. Scientists and regulators turned their attention to creating knowledge about vernal pool ecology, building education programs to raise awareness about vernal pools, and establishing relationships with diverse stakeholders (Fig. 2).

An environmental NGO and the state university developed a citizen science vernal pool mapping and assessment program in 1999. As vernal pools are so widely distributed across the landscape and the peak of activity occurs during a relatively brief window in spring, citizen science became a key strategy to fill data gaps. The Very Important Pool (VIP) program (1999-2004) trained 52 citizens to collect data on approximately 300 vernal pools in four towns in southern, central, and northern Maine. Citizen scientists included a mix of retirees, professionals from consulting and environmental management organizations, student service learning groups, and families. The primary objective was to assess pool physical characteristics, landscape setting, and presence of pool-breeding amphibians (Calhoun et al. 2003).

Citizen science data were then used in peer-reviewed scientific articles about vernal pools (e.g., Calhoun et al. 2003, 2005, Oscarson and Calhoun 2007). The peer-reviewed science associated with the program provided information to support the changes to Maine's Natural Resource Protection Act in 2007 to regulate a subset of vernal pools classified as Significant Vernal Pools. The identification of significance criteria and the resulting legislation used citizen science program data to set egg mass thresholds for "significance" and to help establish timing for pool surveys.

Although the citizen science program provided useful data, the 2007 regulation was still highly controversial (Calhoun et al. 2014). Following passage of the vernal pool regulation, a second citizen science program, the Vernal Pool Mapping and
Assessment Program (VPMAP), was launched in 12 Maine towns as a response to the regulatory controversy. VPMAP included more than 140 volunteer citizen scientists who logged more than 3300 volunteer hours over three field seasons and gained permission to access more than 400 privately owned parcels (Calhoun, unpublished data). VPMAP was designed to provide the State, municipalities, and landowners with a database of potential and assessed pools to allow for informed planning and regulatory predictability (Jansujwicz et al. 2013a,b).

Output 1: Producing information and filling knowledge gaps with citizen science

In the case of vernal pools, there was an early need to better understand the habitat requirements and reproductive efforts of species and the distribution of different vernal pool types across a very broad geographic area. Citizen science was essential for collecting data and filling knowledge gaps about pools. The information on reproductive effort collected by citizen scientists was used by biologists who were reporting to the state legislature during the initial legislative hearings (see Outputs, Fig. 2). The value of this approach was affirmed when special language was added in rule-making that recognized the validity and acceptance of data collected by trained citizens for submission to the state database of recognized exemplary pools (Natural Resources Protection Act, 38 MRSA, Chapter 335). Because the regulation was highly controversial, the fact that these data were also incorporated into formal peer review gave the citizen sciencegenerated data the credibility it needed to withstand the scrutiny and deliberation that occurred in the regulatory process. This is consistent with Dietz et al.'s (2003:1908) observation that "Information systems that simultaneously meet high scientific standards and serve ongoing needs of decision-makers and users are particularly useful" to support the formation of adaptive governance.

The development and dissemination of education and outreach materials for citizen scientists also helped raise public awareness about vernal pools, and build ecological literacy that is essential for resilience (Folke et al. 2002). The VIP program produced The Maine Citizen's Guide to Identifying and Documenting Vernal Pools $(1999,2003)$, which was widely distributed to citizens and the forest industry. Two lay manuals-Best Development Practices for Development around Pools (Calhoun and Klemens 2002) and Habitat Management Guidelines for Forestry (Calhoun and deMaynadier 2004) — provided tools for voluntary stewardship of pool resources and for engaging key stakeholders. Project leaders hosted more than 50 workshops and public presentations for foresters, land trusts, schools, nature clubs, and other citizen groups. As one municipal planner described, "I knew virtually nothing about vernal pools before this project. I had no idea ... that they potentially dried out every year and that they provided so much biomass for other things to live on" (Jansujwicz et al. 2013a). In 2007, a statewide study of local decision-makers demonstrated that most planning board members were familiar with the term vernal pool and expressed positive attitudes toward vernal pools in general (McGreavy et al. 2012).

Output 2: Information sharing, relationship development, and network formation

As awareness of the concept of vernal pools grew, program leaders noted higher attendance at public hearings and increases in the number of hits on the project website. One municipal official 
described how the increasing awareness promoted the capacity for subsequent efforts within towns to survey vernal pools: "The Council invited [a university representative] to come in and talk about vernal pools because the council didn't really understand them at the time. I think that's blossomed into a wonderful relationship. We've done the survey. Did [the other town] do a survey? (Interviewer: Yes.) The same kind of thing? (Interviewer: Yes.) I think that's just great." This quote and the one in the paragraph above show how the education activities in the early years of the program generated the scientific information that supported decision-making (Dietz et al. 2003) while at the same time educating stakeholders about the ecology and importance of vernal pools (Folke et al. 2002, Olsson et al. 2004b). Because the citizen science program featured iterative and inclusive communication among diverse participants and focused on building relationships as part of the data collection process, what started as a more simple effort to meet information needs and educate people about vernal pools grew into a multilevel transformative learning process that eventually changed the context (Folke et al. 2009, Pahl-Wostl 2009) and the stressors.

In the process of collecting data, producing knowledge, and building relationships, informal networks between actors and institutions started to form. Network functions, such as information sharing, were enhanced by the diversity of ways in which people participated in the project. For example, in VPMAP, university researchers were largely responsible for coordinating the project and generating outputs like the municipal vernal pool assessment and digital database (Jansujwicz et al. 2013a). Municipal officials recruited volunteers for the program, hosted training sessions, organized and disseminated data collection materials, and requested landowner permission for citizen scientists to survey their property. Landowners were also invited to join citizen scientists on property surveys. Project meetings brought together representatives from multiple towns to learn from each other about program activities, such as the design of landowner letters, compilation of vernal pool maps, field data sheets, and citizen scientist recruitment. New relationships among communities and government entities enhanced information flow and the formation of relationships. These meetings were also essential for creating the conditions for leadership. This approach aligns with recommendations that policy efforts should intentionally strive to build institutions that encourage learning and adaptive capacity (Folke et al. 2002).

Learning and leadership promote readiness for policy innovation The VIP and VPMAP offered multiple options for participation aligned with individual preferences and strengths. Citizen science volunteers could choose to contribute data, collaborate with project leaders and town officials, and co-create different parts of the research and program design, and thus were able to identify what worked best for them and to grow within that role (Shirk et al. 2012). This flexible yet focused program structure allowed diverse forms of leadership to emerge. This leadership proved essential to building capacity, securing necessary funding and related resources, and creating the readiness for the group to respond when windows of opportunity opened up (Olsson et al. 2006) (Fig. 2).

One significant opportunity occurred with the development of the Vernal Pool Streamlining Working Group (VPSWG), an outcome of VPMAP's effort to promote informed planning and regulatory predictability. This working group started in 2010 as a small group of participants, including authors Calhoun and Levesque, and grew over six years into a formal entity with more than 35 active stakeholders, including federal and state agencies responsible for the current vernal pool regulations. The group produced a market-based local alternative to conserve vernal pools that is currently being piloted in two towns, and that may be available to all eligible towns in the U.S. Army Corps of Engineers New England jurisdiction. This type of approach, also known as Tradeable Environmental Allowances, has been shown to have notable advantages when compared with "command and control" governance strategies (Dietz et al. 2003:1909).

To incorporate this new option into the Army Corps of Engineers regulatory authority, the group crafted a federal Special Area Management Plan (SAMP) for vernal pools, which is currently out for public notice, with intended adoption by the Corps in spring 2016. The Maine Vernal Pool SAMP would be incorporated into the New England General Permit, and would give New England municipalities that are emulating the citizen science mapping projects an option for an innovative regulatory alternative to pool regulation that balances economic development and conservation. Citizen science mapping and assessment efforts helped in the selection of the two pilot towns and were essential to the public support each town needed to launch the program.

The ability to pursue policy innovation clearly depends on learning, and when paired with leadership, these adaptive capacities positioned collaborators to be ready to launch the working group and pursue the SAMP when the time was right (Olsson et al. 2006). We identified distinct leadership roles, including visionary (Westley 2002, Olsson et al. 2004b), spanning and network, integration and communication, and problemsolving (Folke et al. 2005, Gunderson et al. 2008), and provide additional details and analysis in Table 1. Visionary leaders helped the group set a clear agenda and provided the sustained motivation and institutional memory from one phase to the next. The university-based ecologist and program coordinators were essential in this role, as demonstrated when one participant said to a program coordinator "[You]...played a really key role of energy and direction, so keeping the ball moving, responding to questions that at the time we didn't have answer to, bringing information back to the group that allowed the conversation to continue in a constructive fashion. I would say that your unit has been like the spark plug." Visionary leaders "are important in establishing functional links within and between organizational levels and therefore facilitating the flow of information and knowledge" (Olsson et al. 2004a:85). Not only did these leaders provide the continuity between program phases, their vision and motivation served as the "spark plug" to initiate and sustain efforts within the group more broadly.

Working in concert with visionary leaders, spanning and network leaders were instrumental in moving across institutional scales, making connections among diverse groups, and promoting governance legitimacy (Cosens 2013). For example, representatives from the Army Corps of Engineers, town planners, and other municipal officials were key spanning and network leaders. Frequently, these leaders used the project documents such as maps 
Table 1. Diverse leadership roles and examples of how knowledge, networks, and leadership promoted the capacity to act within windows of opportunity. Leadership types are adapted from Gunderson et al. (2008), Folke et al. (2002, 2005), and Olsson et al. (2006).

\begin{tabular}{|c|c|}
\hline $\begin{array}{c}\text { Leadership Type } \\
\text { Description } \\
\end{array}$ & Example and Quotes from Case Study \\
\hline \multicolumn{2}{|l|}{ Visionary } \\
\hline $\begin{array}{l}\text { Help the group set a clear agenda and provide the } \\
\text { sustained motivation and institutional memory } \\
\text { between phases }\end{array}$ & $\begin{array}{l}\text { - Program coordinators and ecologists based at the University of Maine shaped the } \\
\text { science and regulatory efforts, built trust among participants, provided sustained resources } \\
\text { for project continuity, and maintained institutional memory between project phases. }\end{array}$ \\
\hline \multicolumn{2}{|l|}{ Spanning and network } \\
\hline $\begin{array}{l}\text { Able to move across scales of government and } \\
\text { institutions and adept at making connections } \\
\text { across groups }\end{array}$ & $\begin{array}{l}\text { - Representatives from the Army Corps of Engineers spanned governmental scales and } \\
\text { promoted legitimacy in the governance. } \\
\text { - Municipal officials who were part of the Vernal Pool Mapping and Assessment Program } \\
\text { (VPMAP) had a strong relationship with a prominent local developer and with a leader of } \\
\text { the town council, both of whom became involved in the Vernal Pool Streamlining } \\
\text { Working Group (VPSWG). These leaders provided essential information and promoted } \\
\text { support for the new regulatory mechanism. } \\
\text { - Town planners made connections between landowners, scientists, municipal officials, and } \\
\text { developers, often using project documents and maps to facilitate conversations. } \\
\text { - Two citizen scientists who were also representatives of a local land trust regularly } \\
\text { attended the VPSWG meetings and helped coordinate the involvement of their } \\
\text { organizations. }\end{array}$ \\
\hline \multicolumn{2}{|l|}{ Integration and communication } \\
\hline $\begin{array}{l}\text { Promote processes of translation and } \\
\text { communication about the need for vernal pool } \\
\text { regulation in municipalities and state legislature } \\
\text { and project-based communication }\end{array}$ & $\begin{array}{l}\text { - A state planner, town planners, and municipal officials became spokespeople for the } \\
\text { program as they recognized the technical and financial value that VPMAP contributed to } \\
\text { towns for proactively mapping pool resources. } \\
\text { - Social scientists studied and provided feedback about municipal, landowner, and other } \\
\text { researcher perceptions in ways that sought to improve program implementation. } \\
\text { - Citizen scientists and landowners wrote letters against legislative proposals to repeal the } \\
\text { law or were vocal supports of vernal pool protections at state hearings. }\end{array}$ \\
\hline \multicolumn{2}{|r|}{ 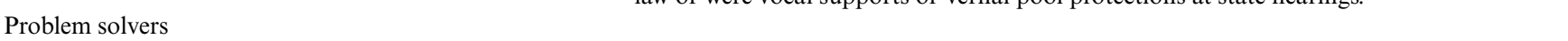 } \\
\hline Reconcile different problems and identify solutions & $\begin{array}{l}\text { - In two towns with limited town resources, citizen scientists volunteered to produce maps, } \\
\text { collect and organize data, and help submit data to the State. } \\
\text { - Social scientists also played a key problem-solving role as their research helped identify } \\
\text { future research needs, such as a study focused on the economic impacts of vernal pool } \\
\text { conservation on private land. This research helped in adjusting targeted communication } \\
\text { strategies by better understanding municipal and landowner questions and concerns } \\
\text { (McGreavy et al. 2012, Jansujwicz et al. 2013a). The vernal pool team began to address } \\
\text { this need by developing fact sheets with "Most Frequently Asked Questions" for use by } \\
\text { planning boards, developers, politicians, and local citizens. Importantly, these were created } \\
\text { in partnership with state and federal regulators. }\end{array}$ \\
\hline
\end{tabular}

and educational materials to help facilitate these connections (Calhoun et al. 2014). This program feature is demonstrated when one planner said "Some people would come in and meet with me, look at the map, and try to understand where the pool was" (Jansujwicz et al. 2013a). Planners became network contacts who listened to landowner questions, provided information about the project, and facilitated getting answers from scientists, functions that have all been identified as essential for adaptive governance (Dietz et al. 2003, Boyd and Folke 2012).

Spanning and network leaders also improved the legitimacy of the adaptive governance (Cosens 2013). In addition to the involvement of municipal officials and town planners, the consistent participation of the representatives from the Army Corps of Engineers proved essential: "Without [Army Corps representative], there would have been no federal approval of this and things would have stopped." The multiple scales of leadership helped build local capacity for understanding regulations and vertical and horizontal networks that promoted coordination among leaders with different but potentially overlapping authority (Cosens 2013). This type of arrangement may be especially important for complex adaptive systems problems because within these distinct arenas "there is experimentation and learning going on," which when "combined with networking of knowledge, creates a diversity of experience and ideas for solving new problems, stimulates innovation, and contributes to creating feedback loops at different scales" (Olsson et al. 2004a:87). Where visionary leaders help prepare a system to respond to change (Gunderson et al. 2008), spanning and network leaders can promote creativity and innovative insights.

Connections, learning, and innovation were further shaped by the roles that social scientists and state and town planners played as integration and communication leaders. The social scientists conducted participant observations, interviews, and focus groups in which they documented perceptions about the project, and then fed their findings back to project coordinators to improve implementation (Jansujwicz and Calhoun 2010, Jansujwicz et al. $2013 a, b)$. One state planner was particularly influential in communicating the need for vernal pool regulation in municipalities and state legislature. This person's role was described in an interview when a participant said "[This person] 
is sort of the last woman standing in terms of planning efforts in the State of Maine. She successfully gets the ear of her committee and elected officials, so I think she's a great promoter at the state level in terms of 'Why we're doing this, why it's important to hold onto growth planning, what we have left, and here's an example of how it meets the needs and interests of the current administration." Town planners played a similar role yet on a different scale, as one said: "What I tried to stress was that...this is a law. People are going to have to deal with vernal pools, and if we can proactively identify them, we are going to assist people. We are going to ease development by knowing ahead of time what is or is not on their property. And I think that was really the selling point" (Jansujwicz et al. 2013a). This town planner helped communicate the need for coordinated efforts and how this was a problem-solving opportunity.

Problem solving became an important leadership role, one frequently adopted by the citizen scientists themselves. These individuals were able to identify needs for creative solutions and additional capacities for mapping, program development, and landowner relations. Two towns did not have the capacity to participate because they lacked town planners and other resources like digitized tax maps. Recognizing the need to solve the problem of limited resources, citizen scientists in these towns stepped in to coordinate mapping by hand and to provide other organizational support, including hosting meetings and garnering local participation. Citizen scientists were also instrumental in providing ongoing formative feedback as they identified problems with training materials and vernal pool data collection forms. Importantly, the project was designed to incorporate this type of feedback through formal interviews with citizen scientists and through iterative evaluation efforts. Finally, maintaining communication and building relationships with the many landowners in the municipalities was a key challenge in the program (Jansujwicz et al. 2013a). Though logistical constraints prevented many landowners from accompanying citizen scientists out into the field to map pools, citizen scientists addressed the problem of landowner engagement by following up after the survey to share what they had found in ways that made landowners more aware of and interested in the pools on their properties (Jansujwicz et al. 2013a).

The citizen science program was designed so that people had clearly defined roles, but they also had flexibility in how they performed those roles and had access to other participation options. Though the following example is based on a single individual, it is also representative of how the program design promoted leadership and innovation for transformative outcomes. One municipal planner, who was also a tax assessor for the town and was involved in the vernal pool mapping effort, took a proactive role in advocating for research on how vernal pool conservation affects property values and local economies. This participant arranged for a presentation about the program to a state-level tax assessor meeting, and it was at this meeting that a well-known economist who had been invited to participate decided to join the project. Collaborators then successfully pursued a National Science Foundation Coupled Natural Human Systems grant directly focused on creating a vernal pool research program that combined ecological and economic research foci. The tax assessor brought a unique perspective and had the space within the program structure to articulate and pursue this identified interest. The citizen science program created the conditions for these subsequent interactions, which led to five more years of research to advance integration of the human dimensions in natural resources conservation.

\section{Recommendations for citizen science program design and policy transformation}

Core elements within the citizen science program enabled the development of an innovative approach to vernal pool regulation (see Program Design, Fig. 2). Knowledge about system interactions and status (Folke et al. 2002), networks that help move knowledge across domains (Dietz et al. 2003), and diverse leaders who promote responsiveness allowed the identification of, and capacity to act within, windows of opportunity (Olsson et al. 2006). When opportunities to advance vernal pool regulatory approaches arose, an informed and connected cadre of collaborators was ready to step in. We identified the following specific program features that supported the development of adaptive capacities from these efforts to generate knowledge, build networks, and create opportunities for leadership:

Create a system for internal project evaluation and learning: While the citizen science program promoted SES resilience, it is important to note that perspectives about the citizen science program were not uniformly positive. The communication among the coordinators, municipal planners, and landowners in the VPMAP program needed improvement, as information transfer is often challenging (Jansujwicz et al. 2013a). The social scientists' participation allowed the identification of these and other issues, which created a system that was ready to identify and work through differences and conflict (Dietz et al. 2003). Program coordinators could then adjust the program to improve information sharing and relationship development, and to identify opportunities for leadership to advance the project. This system of evaluation is thus essential to productively engage conflict and promote transformative learning (Folke et al. 2009, Pahl-Wostl 2009).

Publish scientific studies using citizen science data: Data collected by citizen scientists can be comparable to those collected by trained experts (Oscarson and Calhoun 2007, Kremen et al. 2011). However, one cannot expect policy-makers to have familiarity with the demonstrated validity of this method. When a citizen science program intends to provide data to inform a regulatory process, it may be essential to subject those data to peer review and publishing to promote the perceived legitimacy and credibility (Cash et al. 2003) and to conform to high standards for evidence should the science be questioned (Dietz et al. 2003). Incorporating formal recognition of the validity of citizen science data in rule-making, as occurred in the vernal pool regulation, is a specific strategy to strengthen the status of citizen science data in natural resource policy.

Pursue resources for program sustainability: Securing and distributing funds to improve capacities to respond to change and for ongoing self-organization is crucial (Olsson et al. 2004a). In our case, program coordinators garnered funds from private foundations, NGOs, state agencies, the University of Maine, the National Science Foundation, and the U.S. Environmental Protection Agency. Four graduate students devoted their graduate work to the citizen science and mapping programs and their outcomes. Towns involved in the mapping program directly 
benefited from the in-kind or direct financial support, and these funds promoted their ability to join the effort and continue to participate. Citizen science served as an action platform through which participants identified the need for resources and could bring the knowledge and networks together to advance requests (Folke et al. 2002).

Plan for leadership diversity and informal networks to promote adaptive governance: Programs that allow participants to become involved in a project in diverse, unique, and complementary ways may be well poised for innovation (Olsson et al. 2006). Program planners can encourage diverse leadership and network building by inviting participants from a wide array of institutions, including individuals who work across scales of government, such as municipal planners, state agency representatives, and federal regulators, and from social groups, such as students and teachers, families, and private landowners. These participants enhance the learning, connectivity, and problem-solving potential in groups, and as our vernal pool case shows, can promote adaptive forms of governance to address complex natural resource policy issues.

\section{CONCLUSION}

By producing necessary scientific knowledge in ways that simultaneously built networks among diverse actors and institutions, the citizen science programs that were the focus of this case study promoted information sharing and learning processes so that collaborators could engage in multiple cycles of policy innovation and transformation. The flexible citizen science program structure consistently brought participants together in shared decision-making spaces, and in doing so, created the contexts in which diverse leadership roles could form. Leaders working at different phases and project scales identified and were ready to act within windows of opportunity for policy transformation. This case identifies specific citizen science program design strategies that create credible and legitimate knowledge, networks across diverse actors and institutions, transformative learning processes, and leadership as an emergent system property which support the development of innovative policies and adaptive governance for natural resource management.

Responses to this article can be read online at: http://www.ecologyandsociety.org/issues/responses. $\mathrm{php} / 8437$

\section{Acknowledgments:}

This is Maine Agricultural and Forest Experiment Station Publication No. 3483.

\section{LITERATURE CITED}

Anderies, J. M., B. H. Walker, and A. P. Kinzig. 2006. Fifteen weddings and a funeral: case studies and resilience- based management. Ecology and Society 11(1):21.

Berkes, F., and C. Folke. 2000. Linking social and ecological systems for resilience and sustainability. Pages 1-25 in F. Berkes, C. Folke, and J. Colding, editors. Linking social and ecological systems: management practices and social mechanisms for building resilience. Cambridge University Press, Cambridge, UK.

Bodin, Ô., and C. Prell. 2011. Social networks and natural resource management: uncovering the social fabric of environmental governance. Cambridge University Press, New York, New York, USA. http://dx.doi.org/10.1017/cbo9780511894985

Bonney, R., C. B. Cooper, J. Dickinson, S. Kelling, T. Phillips, K. V. Rosenberg, and J. Shirk. 2009. Citizen science: a developing tool for expanding science knowledge and scientific literacy. BioScience 59:977-984. http://dx.doi.org/10.1525/bio.2009.59.11.9

Boyd, E., and C. Folke, editors. 2012. Adapting institutions: governance, complexity, and social-ecological resilience. Cambridge University Press, New York, New York, USA. http://dx.doi. org/10.1017/cbo9781139017237

Brossard, D., B. Lewenstein, and R. Bonney. 2005. Scientific knowledge and attitude change: the impact of a citizen science project. International Journal of Science Education 27:1099-1121. http://dx.doi.org/10.1080/09500690500069483

Calhoun, A. J. K., and P. deMaynadier. 2004. Forestry habitat management guidelines for vernal pool wildlife. MCA Technical Paper No. 6, Metropolitan Conservation Alliance, Wildlife Conservation Society, Bronx, New York, USA.

Calhoun, A. J. K., and P. G. deMaynadier, editors. 2008. Science and conservation of vernal pools in northeastern North America. CRC Press, Boca Raton, Florida, USA. http://dx.doi. org/10.1201/9781420005394

Calhoun, A. J. K., J. S. Jansujwicz, K. P. Bell, and M. L. Hunter. 2014. Improving management of small natural features on private lands by negotiating the science-policy boundary for Maine vernal pools. Proceedings from the National Academy of Sciences of the United States of America 111(3):11002-11006. http://dx. doi.org/10.1073/pnas.1323606111

Calhoun, A. J. K., and M. W. Klemens. 2002. Best development practices: conserving pool-breeding amphibians in residential and commercial developments in the northeastern United States. MCA Technical Paper No. 5, Metropolitan Conservation Alliance, Wildlife Conservation Society, Bronx, New York, USA.

Calhoun, A. J. K., N. A. Miller, and M. W. Klemens. 2005. Conserving pool-breeding amphibians in human-dominated landscapes through local implementation of Best Development Practices. Wetlands Ecology and Management 13(3):291-304. http://dx.doi.org/10.1007/s11273-004-7523-8

Calhoun, A. J. K., D. Morgan, and R. Carey. 2010. Maine vernal pools project. University of Maine, Orono, Maine, USA. http:// www.umaine.edu/vernalpools/

Calhoun, A. J. K., and P. Reilly. 2008. Conserving vernal pool habitat through community based conservation. Pages 319-341 in A. J. K. Calhoun and P. G. deMaynadier, editors. Science and conservation of vernal pools in northeastern North America. CRC Press, Boca Raton, Florida, USA. http://dx.doi.org/10.1201/97$\underline{81420005394 . \operatorname{ch} 16}$

Calhoun, A. J. K., T. E. Walls, S. S. Stockwell, and M. McCollough. 2003. Evaluating vernal pools as a basis for conservation strategies: a Maine case study. Wetlands 23(1):7081. http://dx.doi.org/10.1672/0277-5212(2003)023[0070:evpaab] 2.0.co; 2 
Cash, D. W., W. C. Clark, F. Alcock, N. M. Dickson, N. Eckley, D. H. Guston, J . Jäger, and R. B. Mitchell. 2003. Knowledge systems for sustainable development. Proceedings of the National Academy of Sciences of the United States of America 100 (14):8086-8091. http://dx.doi.org/10.1073/pnas.1231332100

Chapin, F. S., C. Folke, and G. P. Kofinas. 2009. A framework for understanding change. Pages 3-28 in F. S. Chapin, G. P. Kofinas, and C. Folke, editors. Principles of ecosystem stewardship. Springer, New York, New York, USA. http://dx.doi. org/10.1007/978-0-387-73033-2 1

Colburn, E. A. 2004. Vernal pools: natural history and conservation. McDonald \& Woodward Publishing Company, Blacksburg, Virginia, USA.

Cosens, B. A. 2013. Legitimacy, adaptation, and resilience in ecosystem management. Ecology and Society 18(1):3. http://dx. doi.org/10.5751/ES-05093-180103

Couvet, D., F. Jiguet, R. Julliard, H. Levrel, and A. Teyssedre. 2008. Enhancing citizen contributions to biodiversity science and public policy. Interdisciplinary Science Reviews 33(1):95-103. http://dx.doi.org/10.1179/030801808X260031

Crain, R., C. Cooper, and J. L. Dickinson. 2014. Citizen science: a tool for integrating studies of human and natural systems. Annual Review of Environment and Resources 39(1):641-665. http://dx.doi.org/10.1146/annurev-environ-030713-154609

Crall, A. W., R. Jordan, K. Holfelder, G. J. Newman, J. Graham, and D. M. Waller. 2012. The impacts of an invasive species citizen science training program on participant attitudes, behavior, and science literacy. Public Understanding of Science http://dx.doi. org/10.1177/0963662511434894

Crona, B., and Ô. Bodin. 2012. Knowledge, social networks and leadership: setting the stage for the development of adaptive institutions? Pages 11-36 in E. Boyd and C. Folke, editors. Adapting institutions: governance, complexity, and socialecological resilience. Cambridge University Press, New York, New York, USA. http://dx.doi.org/10.1017/cbo9781139017237.005

Crona, B., H. Ernstson, C. Prell, M. Reed, and K. Hubacek. 2011. Combining social network approaches with social theories to improve understanding of natural resource governance. Pages 44 72 in Ô. Bodin and C. Prell, editors. Social networks and natural resource management: uncovering the social fabric of environmental governance. Cambridge University Press, New York, New York, USA. http://dx.doi.org/10.1017/cbo9780511894985.004

Dibello, F. J., A. J. K. Calhoun, D. E. Morgan, and A. F. Shearin. 2016. Efficiency and detection accuracy using print and digital stereo aerial photography for remotely mapping vernal pools in New England landscapes. Wetlands 36:505-514. http://dx.doi. org/10.1007/s13157-016-0759-2

Dickinson, J. L., and R. Bonney, editors. 2012. Introduction: why citizen science? In Citizen science: public participation in environmental research. Cornell University Press, Ithaca, New York, USA.

Dickinson, J. L., B. Zuckerberg, and D. N. Bonter. 2010. Citizen science as an ecological research tool: challenges and benefits. Annual Review of Ecology, Evolution, and Systematics 41:149-172. http://dx.doi.org/10.1146/annurev-ecolsys-102209-144636
Dietz, T., E. Ostrom, and P. C. Stern. 2003. The struggle to govern the commons. Science 302:1907-1912. http://dx.doi.org/10.1126/ science. 1091015

Folke, C., S. Carpenter, T. Elmqvist, L. Gunderson, C. S. Holling, and B. Walker. 2002. Resilience and sustainable development: building adaptive capacity in a world of transformations. Ambio 31:437-440. http://dx.doi.org/10.1579/0044-7447-31.5.437

Folke, C., S. Carpenter, B. Walker, M. Scheffer, T. Chapin, and J. Rockstrom. 2010. Resilience thinking: integrating resilience, adaptability and transformability. Ecology and Society 15(4):20. http://www.ecologyandsociety.org/vol15/iss4/art20/

Folke, C., F. S. Chapin, and P. Olsson. 2009. Transformations in ecosystem stewardship. Pages 103-1125 in F. S. Chapin, G. P. Kofinas, and C. Folke, editors. Principles of ecosystem stewardship. Springer, New York, New York, USA. http://dx.doi. org/10.1007/978-0-387-73033-2 5

Folke, C., T. Hahn, P. Olsson, and J. Norberg. 2005. Adaptive governance of social-ecological systems. Annual Review of Environment and Resources 30:441-473. http://dx.doi.org/10.1146/ annurev.energy.30.050504.144511

Gelcich, S., T. P. Hughes, P. Olsson, C. Folke, O. Defeo, M. Fernández, S. Foale, L. H. Gunderson, C. RodrÃguez-Sickert, M. Scheffer, R. S. Steneck, and J.C. Castilla. 2010. Navigating transformations in governance of Chilean marine coastal resources. Proceedings of the National Academy of Sciences of the United States of America 107(39):16794-16799. http://dx.doi. org/10.1073/pnas.1012021107

Goldstein, B. E. 2008. Skunkworks in the embers of the cedar fire: enhancing resilience in the aftermath of disaster. Human Ecology 36:15-28. http://dx.doi.org/10.1007/s10745-007-9133-6

Gunderson, L. H., G. Peterson, and C. S. Holling. 2008. Practicing adaptive management in social-ecological systems. Pages 223-245 in J. Norberg and G. S. Cumming, editors. Complexity theory for a sustainable future. Columbia University Press, New York, New York, USA.

Hart, D. D., and A. J. K. Calhoun. 2010. Rethinking the role of ecological research in the sustainable management of freshwater ecosystems. Freshwater Biology 55:258-269. http://dx.doi. org/10.1111/j.1365-2427.2009.02370.x

Jansujwicz, J. S., and A. J. K. Calhoun. 2010. Protecting natural resources on private lands: the role of collaboration in land-use planning. Pages 205-233 in S. Trombulak and R. F. Baldwin, editors. Landscape-scale conservation planning. Springer-Verlag, New York, New York, USA. http://dx.doi.org/10.1007/978-90-4$\underline{81-9575-6 \quad 10}$

Jansujwicz, J. S., A. J. K. Calhoun, J. E. Leahy, and R. J. Lilieholm. $2013 b$. Using mixed methods to develop a frame-based private landowner typology. Society \& Natural Resources 26(8):945-961. http://dx.doi.org/10.1080/08941920.2012.729294

Jansujwicz, J. S., A. J. K. Calhoun, and R. J. Lilieholm. $2013 a$. The Maine Vernal Pool Mapping and Assessment Program: engaging municipal officials and private landowners in community-based citizen science. Environmental Management 52:1369-1385. http://dx.doi.org/10.1007/s00267-013-0168-8 
Jasanoff, S. 2004. Ordering knowledge, ordering society. Pages 25-98 in S. Jasanoff, editor. States of knowledge: the co-production of science. Routledge, New York, New York, USA.

Jordan, R. C., H. L. Ballard, and T. B. Phillips. 2012. Key issues and new approaches for evaluating citizen-science learning outcomes. Frontiers in Ecology and the Environment 10(6):307309. http://dx.doi.org/10.1890/110280

Jordan, R. C., A. Crall, S. Gray, T. Phillips, and D. Mellor. 2015. Citizen science as a distinct field of inquiry. BioScience 65:208211. http://dx.doi.org/10.1093/biosci/biu217

Jordan, R. C., S. A. Gray, D. V. Howe, W. R. Brooks, and J. G. Ehrenfeld. 2011. Knowledge gain and behavioral change in citizen-science programs. Conservation Biology 25(6):1148-1154. http://dx.doi.org/10.1111/j.1523-1739.2011.01745.x

Kneitel, J. M. 2014. Inundation timing, more than duration, affects the community structure of California vernal pool mesocosms. Hydrobiologia 732:71-83. http://dx.doi.org/10.1007/ s10750-014-1845-1

Kremen, C., K. S. Ullmann, and R. W. Thorp. 2011. Evaluating the quality of citizen-scientist data on pollinator communities. Conservation Biology 25:607-617. http://dx.doi.org/10.1111/ j.1523-1739.2011.01657.x

Lebel, L., J. M. Anderies, B. Campbell, C. Folke, S. HatfieldDodds, T. P. Hughes, and J. Wilson. 2006. Governance and the capacity to manage resilience in regional social-ecological systems. Ecology and Society 11(1):19. http://www.ecologyandsociety. org/vol11/iss1/art19/

Levesque, V. R., A. J. K. Calhoun, K. P. Bell, and T. R. Johnson. 2016. Turning contention into collaboration: engaging power, trust, and learning in collaborative networks. Society \& Natural Resources. http://dx.doi.org/10.1080/08941920.2016.1180726

Lowman, M., C. D’Avanzo, and C. Brewer. 2009. A national ecological network for research and education. Science 323 (5918):1172-1173. http://dx.doi.org/10.1126/science.1166945.

Mahaney, W. S., and M. W. Klemens. 2008. Conserving vernal pools in human-modified landscapes vernal pool conservation policy: the federal, state, and local context Pages 193-212 in A. J. K. Calhoun and P. G. deMaynadier, editors. Science and conservation of vernal pools in northeastern North America. CRC Press, Boca Raton, Florida, USA.

Marion, R., and M. Uhl-Bien. 2001. Leadership in complex organizations. Leadership Quarterly 12(4):389-418. http://dx.doi. org/10.1016/S1048-9843(01)00092-3

McGreavy, B., T. Webler, and A. J. K. Calhoun. 2012. Science communication and vernal pool conservation: a study of local decision maker attitudes in a knowledge-action system. Journal of Environmental Management 95:1-8. http://dx.doi.org/10.1016/ j.jenvman.2011.09.020

McKinley, D. C., R. D. Briggs, and A. M. Bartuska. 2012. When peer-reviewed publications are not enough! Delivering science for natural resource management. Forest Policy and Economics 21:111. http://dx.doi.org/10.1016/j.forpol.2012.03.007
Miller-Rushing, A., R. Primac, and R. Bonney. 2012. The history of public participation in ecological research. Frontiers in Ecology and the Environment 10:285-290. http://dx.doi.org/10.1890/110278

Olsson, P., C. Folke, and F. Berkes. 2004a. Adaptive comanagement for building resilience in social-ecological systems. Environmental Management 34(1):75-90. http://dx.doi. org/10.1007/s00267-003-0101-7

Olsson, P., C. Folke, and T. Hahn. 2004b. Social-ecological transformation for ecosystem management: the development of adaptive co-management of a wetland landscape in southern Sweden. Ecology and Society 9(4):2.

Olsson, P., V. Galaz, and W. J. Boonstra. 2014. Sustainability transformations: a resilience perspective. Ecology and Society 19 (4):1. http://dx.doi.org/10.5751/es-06799-190401

Olsson, P., L. H. Gunderson, S. R. Carpenter, P. Ryan, L. Lebel, C. Folke, and C. S. Holling. 2006. Shooting the rapids: navigating transitions to adaptive governance of social-ecological systems. Ecology and Society 11(1):18.

Oscarson, D. B., and A. J. K. Calhoun. 2007. Developing vernal pool conservation plans at the local level using citizen-scientists. Wetlands 27:80-95. http://dx.doi.org/10.1672/0277-5212(2007)27 [80:DVPCPA] 2.0.CO;2

Pahl-Wostl, C. 2009. A conceptual framework for analysing adaptive capacity and multi-level learning processes in resource governance regimes. Global Environmental Change 19(3):354-365. http://dx.doi.org/10.1016/j.gloenvcha.2009.06.001

Palmer, M. A. 2012. Socioenvironmental sustainability and actionable science. BioScience 62(1):5-6. http://dx.doi.org/10.1525/ bio.2012.62.1.2

Phillips, T., R. Bonney, and J. L. Shirk. 2012. What is our impact? Toward a unified framework for evaluating outcomes of citizen science participation. Pages 82-95 in J. Dickinson and R. Bonney, editors. Citizen science: public participation in environmental research. Cornell University Press, Ithaca, New York, USA.

Seixas, C. S., and F. Berkes. 2003. Dynamics of social-ecological changes in a lagoon fishery in southern Brazil. Pages 271-298 in F. Berkes, J. Colding, and C. Folke, editors. Navigating socialecological systems: building resilience for complexity and change. Cambridge University Press, New York, New York, USA. http:// dx.doi.org/10.1017/cbo9780511541957.017

Sendzimir, J., P. Magnuszewski, Z. Flachner, P. Balogh, and G. Molnar. 2008. Assessing the resilience of a river management regime: informal learning in a shadow network in the Tisza River Basin. Ecology and Society 13(1):11.

Shirk, J. L., H. L. Ballard, C. C. Wilderman, T. Phillips, A. Wiggins, R. C. Jordan, E. McCallie, M. Minarchek, B. V. Lewenstein, M. E. Krasny, and R. Bonney. 2012. Public participation in scientific research: a framework for deliberate design. Ecology and Society 17(2):29. http://dx.doi.org/10.5751/ es-04705-170229

Tiner, R. W., editor. 2009. Status report for the National Wetlands Inventory Program: 2009. U.S. Fish and Wildlife Service, Division 
of Habitat and Resource Conservation, Branch of Resource and Mapping Support, Arlington, Virginia, USA.

Tuytens, K., B. Vanschoenwinkel, A. Waterkeyn, and L. Brendonck. 2014. Predictions of climate change infer increased environmental harshness and altered connectivity in a cluster of temporary pools. Freshwater Biology 59(5):955-968. http://dx. doi.org/10.1111/fwb.12319

Westley, F. 2002. The devil in the dynamics: adaptive management on the front lines. Pages 333-360 in L. H. Gunderson and C. S. Holling, editors. Panarchy: understanding transformations in human and natural systems. Island Press, Washington, D.C., USA.

Yin, R. K. 2013. Case study research: design and methods. Sage Publications, Thousand Oaks, California, USA. 